\title{
HR ROLES - THE STATE-OF-THE-ART AND CHALLENGES
}

\author{
Aneta KARASEK \\ UMCS, Faculty of Economics; aneta.karasek@umcs.pl, ORCID: 0000-0002-6055-5150
}

Purpose: The aim of this paper is to identify roles played by HR departments in Polish innovative enterprises.

Design/methodology/approach: A critical analysis of literature, research results and reports analysis helped to achieve the aim. In order to identify the tasks performed by HR departments, D. Ulrich's model was employed.

Findings: The roles most commonly performed by the HR departments of the analysed enterprises were those of administrative expert and employee champion. The roles of strategic partner and change agent were somewhat less commonly undertaken. Moreover, HR departments most commonly undertake activities aimed at creating a good working atmosphere, analysing employees' competences and allowing them to develop, as well as quick and efficient processing employee matters.

Digital transformation results in a change of expectations towards HR departments. The challenges faced by HR departments will revolve around the implementation of IT solutions in enterprises, improving the efficiency of employee management, and coping with the expectations of future employees from generation $\mathrm{Y}$ and $\mathrm{Z}$.

Practical implications: The HR department should perform new tasks within its roles. Given the simultaneous benefits and concerns related to digital transformation, it will fall to HR departments to assume the role of change agent by ensuring their organisations' capacity for change, as well as administrative expert responsible for reengineering organisational processes.

Originality/value: The tasks and roles played by HR department in innovative enterprises were identified. By analysing trends on the market, it was concluded that the HR departments are facing challenges.

Keywords: HR roles, HR department, HR analytics, digital transformation, innovation.

Category of the paper: Research paper. 


\section{Introduction}

Over the years, the approach to the personnel function evolved along with the perception of the human factor. The whole idea of HR is based on the assumed existence of goals shared by the employers and their employees. Therefore, it is necessary for HR personnel to take steps aimed at building a proper employee relations (Ingham, and Ulrich, 2016). Human resources departments now play a significant role in the overall management of personnel. Innovative enterprises require employees with technical skills, industry knowledge, as well as skills to solve problems and IT skills (including knowledge of programming and algorithm development) (Golińska-Pieszyńska, and Batorowicz, 2018, pp. 251), whose acquisition and development is the responsibility of the HR department. In the opinion of D. Ulrich and W. Brockbank, the fundamental tasks of HR include focusing on strategic goals, identifying and serving target customers, ensuring the company's financial success, and implementing the employee value model (Ulrich, and Brockbank, 2008, pp. 181). In order to cope with the above, effective HR leaders will adapt the work of their department to the needs of the entire organisation and select means adequate for its actual business goals.

Industry 4.0 requires changing the profiles of current positions and creating completely new ones for analysts and IT engineers (Gajdzik, and Grabowska, 2018). Researchers emphasise the need to identify actions that need to be taken with the view of responding to the challenges posed by digital transformation and take advantage of the opportunities it creates in the area of improving HR capabilities, services, and efficiency (DiRomualdo, et al., 2018, pp. 234). In the face of ongoing digital transformation, it is necessary to specify tasks that ought to be performed by the HR department in order to effectively support innovative development of the enterprise and efficient decision-making in the area of employee management.

The aim of this paper is to identify roles played by HR departments in innovative enterprises in Poland. Therefore, an analysis was also performed with regard to the forecasted directions of change in terms of the roles of HR departments in the face of future trends and challenges related to digital transformation. A critical analysis of literature and industry reports allowed the formulation of the following research questions:

1. What tasks do the HR departments perform in innovative enterprises?

2. What roles do HR departments play in Polish innovative enterprises?

3. What challenges for HR departments are posed by digital transformation? 


\section{The roles of HR Department}

Value creation, as the principal task of the human resources function, requires the engagement of employees who will undertake a variety of tasks aimed at effective employee management. HR specialists create value when their work facilitates the achievement of goals adopted by respective stakeholders: employees, in-line managers, customers, and investors, and that value is determined not only by the supplier but also the recipient (Ulrich, and Brockbank, 2008). It is therefore necessary to identify what exactly constitutes value for them and precisely identify steps that need to be taken in order to ensure effectiveness of the work performed by HR departments. Moreover, it is crucial to play the role of employee champion, which has been defined in a way conducive to achieving both business and employee goals (Keegan, and Francis, 2010, pp. 875). Studies conducted on a group of over 100,000 respondents from HR departments allowed D. Ulrich and J. Grochowski to identify 4 phases within which HR departments are able to create value. They observed that the performance of $\mathrm{HR}$ in delivering value is dependent on nine criteria of an effective HR department generating value in four distinct stages (Ulrich, and Grochowski, 2018, pp. 184):

1. Foundational/administrative: HR focuses on efficiency.

2. Functional: HR focuses on best practices.

3. Strategic: HR focuses on delivering strategy.

4. Outside in: HR focuses on stakeholders outside the organization.

The roles assigned to personnel department staff tend to vary depending on the way they are perceived. D. Ulrich suggested a classification of the tasks performed by HR managers and specialists which includes the set of four roles and activities of HR departments that need to be undertaken depending on the result that the given enterprise aims to accomplish. He identified the following roles of HR specialists (Ulrich, 1997):

- Strategic partner - entailing participation in the development and implementation of company strategies by providing expert know-how related to HR and ensuring mutual integration of corporate and HR strategies.

- Change agent - entailing responsibility for the culture of change and obligation to take steps aimed at transforming the organisation.

- Administrative expert - entailing responsibility for continuous pursuit of increased efficiency by reengineering the HR function.

- Employee champion - focused on handling employee matters by identifying their needs and competences and channelling them towards business goals.

Employers are increasingly more likely to include the HR department in the performance of business goals, which offers a considerable competitive edge. Modern enterprises implement the concept of HR specialists as business partners supporting operational managers in implementing business strategies, which renders them responsible before the company as 
a whole and facilitates the expectation that HR will generate tangible value. Under certain circumstances, top management and in-line managers may impose difficult and uncomfortable roles on the HR department when the adopted policies and undertaken activities prove to be economically and ethically detrimental (Kaufman, 2015).

Personnel department staff may perform operational or strategic tasks in the context of HR. In the past, HR's role in the enterprise used to be secondary at best, gradually evolving towards a more supportive capacity (Pocztowski, 2007, pp. 64). However, since the beginning of the 21 st century, we have observed progressing decentralisation and redefinition of the tasks of HR departments. HR departments undoubtedly face a number of considerable challenges brought about by digital transformation, and consequently a variety of new tasks including the transformation of their roles and competences towards a greater focus on innovation, HR analytics, and IT implementation (Deloitte, 2016). D. Ulrich suggested that HR departments need to be transformed if they are to supply value in the form of talents, leadership, and capability (Ulrich, 2016).

The evolving business milieu necessitates changes to the roles normally assumed by HR departments. The growing pressure of global competition has forced organisations to achieve greater operating efficiency and effectiveness. Moreover, it has also been necessary to adapt to changes of various internal factors. In some organisations the conflict between decisions aimed towards development versus those pertaining to cost savings has been a significant problem hindering the exact determination of the HR department's position. Professional reasons encourage HR personnel to further the development and engagement of employees, while at the same time the digital transformation may force them to implement redundancy and outsourcing schemes.

The department's activities may be categorised relative to the respective roles it performs in the enterprise and the same can vary depending on the size and strategic approach of a given company. So it is crucial to identify what tasks are performed by the HR department in innovative enterprises and what roles does the HR department need to perform to provide the expected value to stakeholders. Moreover, it is crucial to indicate what challenges for HR departments are posed by digital transformation.

\section{Research methods}

The study entailed a targeted selection of the research sample. The selection criteria included the following factors: 
- an enterprise conducting economic activity in Poland,

- an enterprise employing at least 10 people,

- an enterprise which implemented at least one product, processual, organizational, or marketing innovation (Oslo Manual, 2006, pp. 49) within the last 2 years.

The study was conducted in innovative enterprises between October 2015 and June 2016. It was assumed that the survey respondents will include managers responsible for managing the enterprises' human resources departments. Ninety-two correctly completed surveys were returned, a majority of which were from small enterprises $(52.2 \%)$, followed by medium enterprises (25.1\%). Large enterprises constituted $20.7 \%$ of the research sample. In terms of the scope of operations, the number of enterprises with international outreach was the largest $30.4 \%(n=28)$, followed by enterprises operating in domestic $-27.2 \%(n=25)$ and regional $27.2 \%(n=25)$ markets. Enterprises operating locally were in the minority $-15.2 \%(n=14)$.

The reliability of the research tool's elements was determined with the use of Cronbach's alpha. It is generally assumed that the value of the reliability index should be 0.65 or higher (Bourque, and Clark, 1999, p. 73). Cronbach's alpha for the relevant variables was: administrative expert (0.82), employee champion (0.82), strategic partner (0.68), and change agent $(0.80)$. The same was indicated by high internal cohesion of the scale.

\section{Research results}

In order to identify the tasks performed by HR departments, D. Ulrich's (Ulrich, 1997) model was employed to distinguish between the four main roles served by them: strategic partner (SP), administrative expert (AE), employee champion (EC), and change agent (CA). The respondents were asked to indicated activities undertaken by employees responsible for managing the personnel grading them on a five-tier scale where 1 corresponded to "never" and 5 to "very often".

The results of the conducted survey (Figure 1) indicate that HR departments most commonly undertake activities aimed at creating a good working atmosphere, analysing the employees' competences and allowing them to develop, as well as quick and efficient processing of employee matters. Moreover, HR staff members often advise employees in solving their problems and perform tasks conducive to increasing the enterprise's innovativeness, e.g.: partaking in crucial decisions (e.g. operational changes), introducing new solutions (e.g. HR administration technologies) and improvements, as well as employee incentive systems that foster innovativeness. In turn, HR departments less commonly contribute to maintaining the employees' work-life balance or develop flexible organizational structures. 
takes steps to create a good working atmosphere (EC)

analyses employee competences and facilitates their development (CA)

quickly and efficiently processes employee matters to ensure employee satisfaction (AE)

advises employees in solving their problems (EC)

participates in decisions crucial to the enterprise (SP)

introduces new solutions, including technological (AE)

implements a system of incentives for employees furthering the enterprise's innovativeness (CA)

develops an HR strategy to facilitate the achievement of business goals (SP)

improves the efficiency of $\mathrm{HR}$ services (AE)

collaborates with the management in developing the general strategy of the enterprise (SP)

enables employees to maintain the proper work-life balance $(\mathrm{EC})$

develops flexible organisational structures conducive to innovativeness (CA)

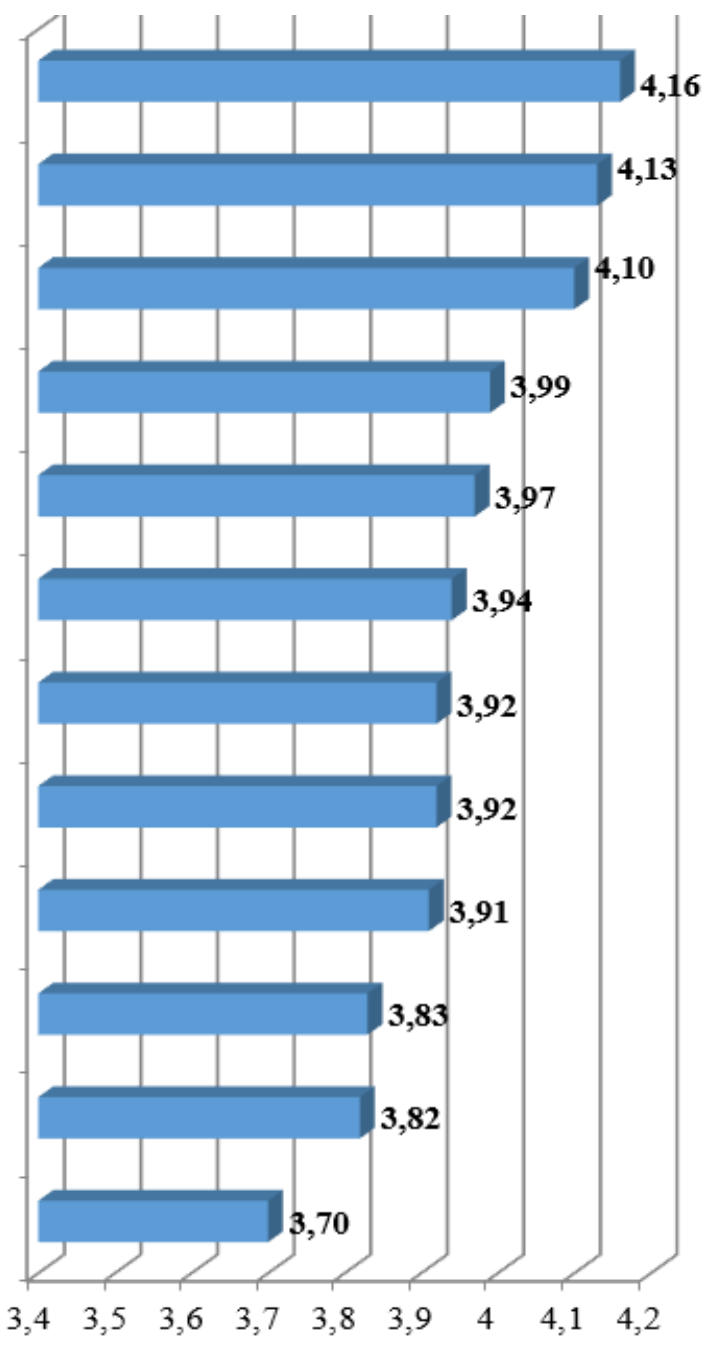

Figure 1. Tasks performed by the HR departments of the analysed enterprises (median). Source: own elaboration based on Karasek (2017).

Respective activities undertaken by HR departments were categorised under one of the identified areas: strategic partner, change agent, employee champion, or administrative expert, as presented in figure 2 below.

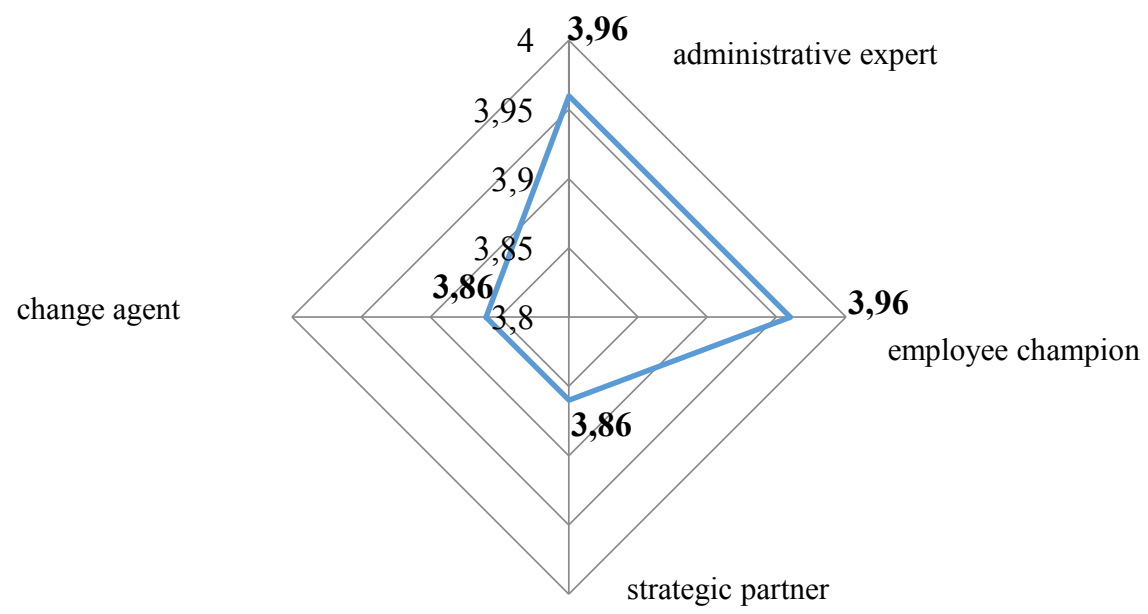

Figure 2. Roles of the HR departments in the analysed enterprises. Source: own elaboration based on Karasek (2017). 
The HR departments of the analysed enterprises played the roles with different frequency. The roles most commonly played were those of administrative expert and employee champion. This suggests that the tasks most commonly performed by the HR personnel included administrating personnel matters, caring for the employees, implementing new solutions and providing them with adequate work conditions. The roles of strategic partners and change agents were somewhat less commonly undertaken.

The contemporary conditions of conducting business trigger a shift in expectations directed towards HR departments. Therefore, an analysis was also performed with regard to the forecasted directions of change in terms of the roles of HR departments in the face of future trends and challenges related to digital transformation. The results of a study conducted among 1,200 global HR executives indicate that approximately two-thirds observed that the digital transformation was underway in their companies and would continue in the future (KPMG, 2018 , p. 8). However, only $40 \%$ claimed to have a work plan ready with regard to the implementation of digital solutions on the corporate or HR level (KPMG, 2018, p. 8). Therefore, it is necessary to identify the tasks to be performed by HR department in order to meet these challenges.

Simultaneously, the introduction of numerous new tools leads to a rapid increase of data generated within businesses. Hence, HR departments will also need to face challenges related to proper data collection and analysis, as well as the process of HR decision-making. The latter is facilitated by HR analytics supporting personnel related decisions by employing both basic indicators and proprietary internal indices to allow effective assessment of particular phenomena observed within the enterprise. However, as indicated by research conducted among CEOs, only 26 percent claim to effectively use the available technologies and analytics, and only 6 percent believe their HR technology to be perfect (Deloitte, 2019, p. 93). Furthermore, 65 percent of the respondents deem their current solutions to be insufficient or only fair relative to the goals adopted by their enterprise (Deloitte, 2019, p. 93). In the context of Polish enterprises, the process of implementing HR analytics solutions is still in its infancy, with only $16 \%$ of SMEs and $19 \%$ of large enterprises taking advantage of them very often, and $32 \%$ of both SMEs and large enterprises utilising them on a regular basis (Wawer, and Muryjas, 2016, p. 311). Moreover, in comparison to large enterprises, SMEs seem to be more likely to use analytics in processes related to employee recruitment and selection, as well as payroll management, and less likely to apply the same in analyses pertaining to absenteeism or personnel turnover.

Members of the $\mathrm{Y}$ and $\mathrm{Z}$ generations are accustomed to utilising SM in their everyday lives and expect similar solutions to be implemented also by their employers. As follows from research (Future Workplace and Randstad, 2016, p. 2), the predominant expectations relating to the implementation of IT solutions are as follows: 
- $41 \%$ social media,

- $27 \%$ wearables,

- $26 \%$ virtual reality,

- $20 \%$ robotics,

- $18 \%$ MOOCs (Massive open online courses),

- $14 \%$ augmented reality.

The obtained results suggest that $\mathrm{Y}$ and $\mathrm{Z}$ generations are, to a varying extent, open to technology deployment in their work environments, which may stem from the level of their overall familiarity with such solutions and previous experience of their use.

HR professionals who view HR strategy and business strategy as integrated in their organisations are significantly more likely to use people data in their practice, suggesting that improving the link between business strategy and HR strategy may help to improve the use of people data by HR professionals (CIPD and Worday, 2018). What follows from the above is that turning HR departments into strategic partners offers better opportunities for more effective use of employee data and utilization of information in decision making and action. The research results show that more than $77 \%$ of HR total impact on customer value and more than $55 \%$ of impact on stakeholder value occurs through HR's involvement in information management (Brockbank et.al, 2018). HR departments will also have to develop and implement ethical principles pertaining to the use of new IT solutions, bearing in mind the shared values of employers and employees alike.

\section{Discussion and summary}

Value creation, as the principal task of HR departments plays a key in the strategic management of human resources by collaborating with executive management in ensuring the performance of business goals by the enterprise's personnel. It also provides expert knowledge and works towards more efficient utilisation of the human resources available. In research on innovative enterprises, the HR department most often played the role of administrative expert and employee champion, and somewhat less commonly that of strategic partner or change agent. In most of the analysed examples, the role of HR department as an administrative expert dominates, and only in large organizations is it still combined with the function of a strategic partner and employee champion (Winnicka-Wejs et al., 2019, p. 16). This suggests that in innovative enterprises striving to increase the efficiency of innovation and generation of pioneering solutions, employees were typically provided with adequate work conditions, cared for, and able to take advantage of reengineered organisational processes. HR departments were relatively less frequently involved in the preparation of business strategies or development of 
flexible organisational structures conducive to innovativeness. In this areas HR department should carry out the task more frequently to achieve higher innovativeness.

By analysing trends on the market, it can be concluded that the challenges faced by HR departments will revolve around the implementation of IT solutions in their enterprises, improving the efficiency of employee management, and coping with the expectations of future employees. Therefore, the HR department should perform new tasks within its roles.

The growing amount of data and availability of HR analytics provides human resources specialists with the ability to adopt the role of strategic partner by indicating the ways of more efficient utilisation of employee competences in the performance of the enterprise's strategy of innovativeness. The implementation of HR analytics will pose a considerable challenge to HR departments and will require enterprises to suitably develop implementation goals and policies. Organisations willing to introduce HR analytics should adopt the top-down approach which facilitates higher levels of corporate adaptation (Vargas et. al., 2018, p. 3060). However, the same will require further development of the capacity for data analysis and application. Therefore, corporate strategies need to be developed jointly by the management and HR personnel which should also be included in decision-making processes crucial to the enterprise's operations. Moreover, by extending the scope of tasks realised by HR departments in this area, their focus shifts from the functional to strategic support of organisational requirements (Tursunbayeva et. al., 2018, p. 224).

The members of generations $\mathrm{Y}$ and $\mathrm{Z}$ who are the future workforce have different preferences and expectations towards their employers when compared to the previous generations. Therefore, HR departments will have to assume the crucial role of employee champion by remaining attentive to their opinions, analysing and effectively responding to the expectations of present and future employees, as well as ensuring the possibility of maintaining a proper life-work balance.

Given the simultaneous benefits and concerns related to digital transformation, it will fall to HR departments to assume the role of change agents by ensuring their organisations' capacity for change, as well as administrative experts responsible for reengineering organisational processes. In their further research, the author wants to explore the subject through empirical studies on employees' and employers' concerns related to the digital transformation. 


\section{References}

1. Bourque, L.B., Clark, V.A. (1999). Processing Data, The Survey Example. Series: Quantitive Applications In the Social Science (Book 85). US: Sage Publications, Inc.

2. Brockbank, W., Ulrich, D., Kryscynski, D.G., Ulrich, M. (2018). The future of HR and information capability. Strategic HR Review, 17(1), pp.3-10, https://doi.org/10.1108/SHR11-2017-0080.

3. DiRomualdo, A., El-Khoury, D., Girimonte, F. (2018). HR in the digital age: how digital technology will change HR's organization structure, processes and roles. Strategic HR Review, 17(5), pp.234-242, https://doi.org/10.1108/SHR-08-2018-0074.

4. Gajdzik, B., Grabowska, S. (2018). The lexicon of terms used in industry 4.0. Scientific Papers of Silesian University of Technology. Organization and Management Series, No. 132, pp. 221-238. http://dx.doi.org/10.29119/1641-3466.2018.132.13.

5. GEN Z AND MILLENNIALS COLLIDE AT WORK, Despite the tech revolution, Gen Z and Millennials crave in-person collaboration (2016). Future Workplace and Randstad. Retrieved from: https://workplacetrends.com/wp-content/uploads/2017/07/Gen-Z-andMillennials-Collide-at-Work-Final.pdf, 3.06.2019.

6. Global Human Capital Trends 2016. The new organization: Different by design, Deloitte. Retrieved from: https:/www2.deloitte.com/pl/pl/pages/human-capital/articles/hr-trendy2016-raport.html; www2.deloitte.com/pl/pl/pages/human-capital/articles/hr-trendy-2016raport.html, 3.06.2019.

7. Golińska-Pieszyńska, M., Batorowicz, B. (2018). Impact of open data on innovation activities of enterprises. Scientific Papers of Silesian University of Technology. Organization and Management Series, No. 132, pp. 239-252. http://dx.doi.org/10.29119/ 1641-3466.2018.132.14.

8. Ingham, J., Ulrich, D. (2016). Building better HR departments. Strategic HR Review, 15(3), pp. 129-136. https://doi.org/10.1108/SHR-03-2016-0025.

9. Karasek, A. (2017). Model zarzadzania zasobami ludzkimi $w$ innowacyjnym przedsiębiorstwie (Doctoral dissertation). Politechnika Śląska, Wydział Organizacji Zarządzania, Zabrze.

10. Kaufman, B.E. (2015). Evolution of Strategic HRM as seen through two founding books: a 30th Anniversary perspective on development of the field. Human Resource Management, 549(3), pp. 389-407. https://doi.org/10.1002/hrm.21720.

11. Keegan, A., Francis, H. (2010). Practitioner talk: The changing textscape of HRM and emergence of HR business partnership. The International Journal of Human Resource Management, 21(6), pp.873-898. https://doi.org/10.1080/09585191003729341. 
12. Leading the social enterprise: Reinvent with a human Focus, 2019 Deloitte Global Human Capital Trends. Retrieved from: https://www2.deloitte.com/content/dam/insights/us/ articles/5136_HC-Trends-2019/DI_HC-Trends-2019.pdf, 3.06.2019.

13. Oslo Manual (2006). Guidelines for Collecting and Interpreting Innovation Data. OECD.

14. People analytics: driving business performance with people data. Global research REPORT, June 2018, CIPD and Workday. Retrieved from: https://www.cipd.co.uk/Images/ people-analytics-report_tcm18-43755.pdf, 3.06.2019.

15. Pocztowski, A. (ed.) (2007). Personal function. Diagnosis and directions of change. Kraków: Publisher of the University of Economics.

16. The future of HR 2019: In the Know or in the No, KPMG International. Retrieved from: https:/home.kpmg/xx/en/home/insights/2018/11/the-future-of-human-resources.html, 3.06.2019.

17. Tursunbayeva, A., DiLauro, S., Pagliari, C. (2018). People analytics-A scoping review of conceptual boundaries and value propositions. International Journal of Information Management, No. 43, pp.224-247. https://doi.org/10.1016/j.ijinfomgt.2018.08.002

18. Ulrich, D. (1997). Human Resource Champions: The Next Agenda for Adding Value and Delivering Results. Boston, MA: Harvard Business Press.

19. Ulrich, D. (2016). HR at a crossroads. Asia Pacific Journal of Human Resources, No. 54, pp.148-164, doi:10.1111/1744-7941.12104.

20. Ulrich, D., Brockbank, W. (2008). Creating value by the HR department. Kraków: Oficyna a Wolters Kluwer business.

21. Ulrich, D., Grochowski, J. (2018). Building a world class HR department. Strategic HR Review, 17(4), pp.181-185, https://doi.org/10.1108/SHR-05-2018-0046.

22. Vargas, R., Yurova, Y.V., Ruppel, C.P., Tworoger, L.C., Greenwood, R. (2018). Individual adoption of HR analytics: a fine grained view of the early stages leading to adoption. The International Journal of Human Resource Management, 29(22), pp.3046-3067, doi: 10.1080/09585192.2018.1446181.

23. Wawer, M., Muryjas, P. (2016). Business analytics in human resource management in the enterprise. Research Papers of the Wroclaw University of Economics/Prace Naukowe Uniwersytetu Ekonomicznego we Wroclawiu, Iss. 429, pp. 307-316. doi: 10.15611/ pn.2016.429.27.

24. Winnicka-Wejs, A., Sokolińska, D., Kawa, H. (2019). Contemporary role of the HR department in the organization. Academy of Management, 3(1), pp. 6-18, ISSN 2544$512 X$. 